\title{
Repressing Repair: Hans Döllgast's Reconception of the Alte Pinakothek, 1946-1973
}

\author{
LYNNETTE WIDDER \\ Columbia University
}

Hans Döllgast's Alte Pinakothek inMunich (1946-73) is seen as a masterpiece of post-war reconstruction, celebrated for its poetic treatment of wartime scars. The building's reception has, however, consistently repressed the technology behind its reconstruction, from the new structural concrete cage inside its patched brick walls to the plumbing and heating needed for a functioning museum. This paper considers the building's reception relative to Döllgast's unpublished technical drawings. Reference to Alois Riegl's theories of monuments and their role in preserving cultural memory, which Döllgast would have known, supports the basis for a revised reading of the Alte Pinakothek to see its technical components as important contributors to its value as memorial and monument.

\section{INTRODUCTION}

In his autobiographical collection of sketches and aphorisms, Journal Retour, first published in 1973 shortly before his death, Munich architect Hans Döllgast included a curious sketch with a bit of text that must have been cryptic for readers not familiar with his travails during the reconstruction of the Alte Pinakothek museum in Munich. "Herr Hohof was right: One should protect ruins, but that is all," he wrote above the sketch. ${ }^{1}$ The sketch depicts the museum building beneath an umbrella, its handle twisted into the monogram he used as a signature. For readers who knew the extent of criticism to which Döllgast was subject, however, and the extent to which his work on this building was characterized again and again as at best provisional, the response to the sketch is one of empathy. Large-scale appreciation of his achievement in fact occurred only after his death. And although it is wrong to see this caricature as accurately representing the nature and extent extent of his intervention into the building, the spirit of much posthumous reception could be said to have mistaken the caricature for reality.

\section{THE ALTE PINAKOTHEK IN ITS IMMEDIATE POST-WAR CONTEXT}

Much of the architecture-related debate in the immediate post-war period in Germany located itself between the poles of reconstruction - for example, the execution of an "historically accurate" facsimile of Goethe's house in Frankfurt - and tabula rasa planning - epitomized by the Kollektivplan for Berlin. In the meantime, German cities literally rose from their own rubble, salvaged by the Trümmerfrauen ("rubble women"), whose efforts later were to earn them government pensions in recognition of their vital role. Although the

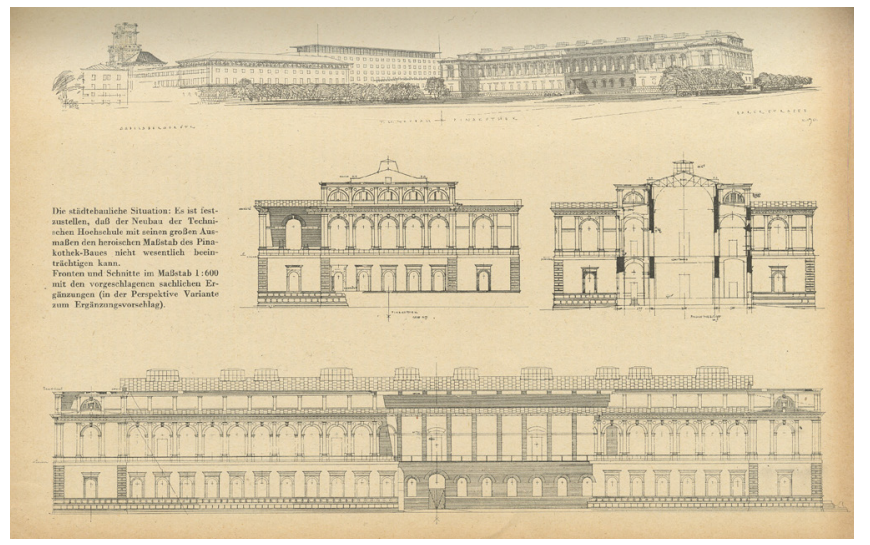

Figure 1: Hans Döllgast, reconstruction of the Alte Pinakothek as published in Baumeister in 1952.

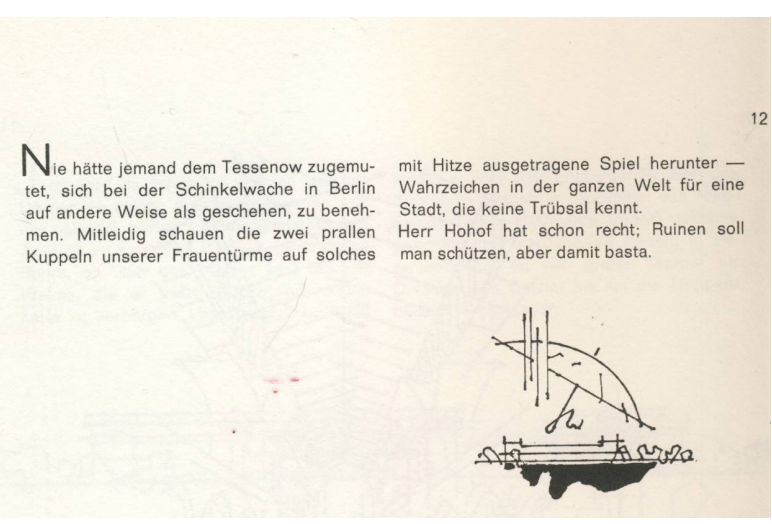

Figure 2: The Alte Pinakothek protected by an umbrella in Döllgast's 1973 Journal Retour.

polarized debate of that period has been defused over time, Döllgast's post-war work continues to be received in scholarly and popular circles as unique - an architecture neither modern nor traditional, neither ruin nor reconstruction and therefore unsentimentally transparent to its historical referents. This tendency is particularly pronounced in the case of his project for the Alte Pinakothek in Munich, a building he championed for some two decades beginning in 1946.

In this paper, I propose a reading of the Alte Pinakothek, in which history is not presumed to be literally representable. To do so, I will extrapolate the particular historical imaginary of Döllgast's oeuvre from his built work and from his books of drawings and aphorisms. I will also draw on the terms defined by Alois Riegl in his1903 essay 'Der moderne Denkmalkultus: Sein Wesen und seine Entstehung' ('The Modern Cult of the 


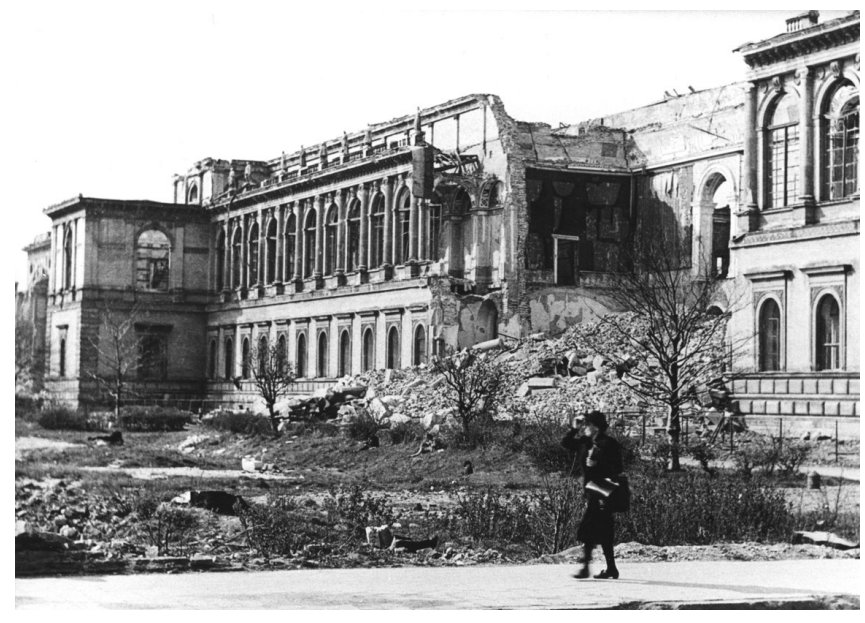

Figure 3: The Pinakothek in ruins in the late 1940s.

Memorial: Its Essence and Genesis'), which proposed a complex paradigm- one which Döllgast would very likely have known well - for the value, reception and historical signification of the monument. Finally, I will consider the technical aspects of Döllgast's reconstruction of the Alte Pinakothek relative to the problem of embodying memory by means of the ruin, in what is intended to be a functioning building.

\section{RUINS, PHENOMENAL AND LITERAL}

Döllgast wrote little about his philosophy of architecture although he was the author of at least ten books. His work at the Technical College of Munich, where he served as professor of freehand and technical drawing from 1943-56, ${ }^{2}$ provided the explicit impetus for these books, but implicitly, they communicate the construction of his own persona and values. In Häuser Zeichen ('Drawing Buildings') of 1957, for example, he presents himself not as an architect, but as a "Hauszeichner" or sketcher of buildings.

It is impossible to make sense of the book's eclectic collection of drawn subjects - ironwork, a small country cottage, the Medieval towns of Franconia, chairs, a nuclear reactor from a distance- without reflecting on its author's values: observation, subtle differentiation, the "more than trivial" everyday. He sees these values in anonymous vernacular buildings and objects, in craft products, in industrial building, in townscapes. They transcend genre and periodization. Döllgast draws them all the same way: shaded, often set in relief by plant life and gradated in detail. The effect implies ephemerality, not only of the drawings, but also, of what is drawn. In fact, the many sketches of ruins, mostly Roman, seem little different from those of intact buildings. Döllgast's words and drawings insinuate that he drew what he thought to be timeless and transcendent, its essence captured in his elliptic sketches. He also explicitly refuses to advocate for either "modern or unmodern (about which there is no discussion here)." ${ }^{\prime 3}$ Döllgast's history of architecture is styleless and timeless; its highpoints do not differ significantly from the buildings and objects of everyday life.
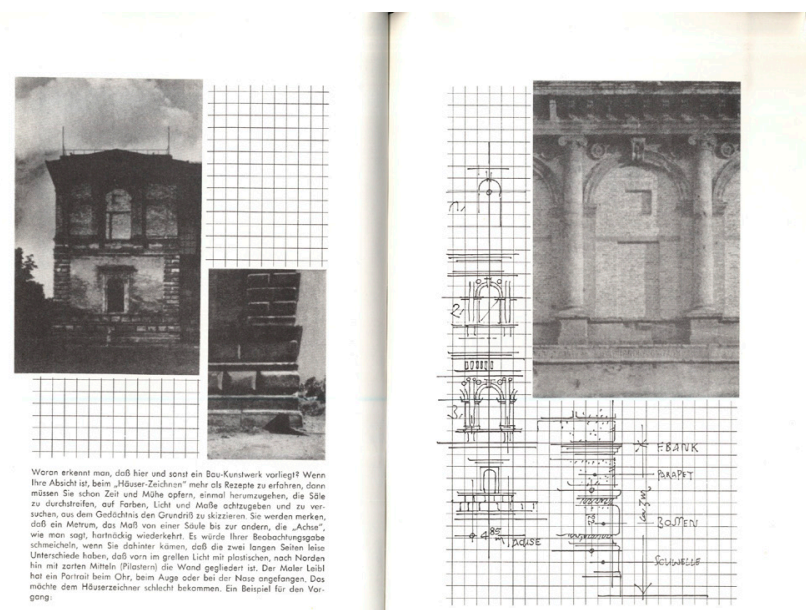

Figure 4: Sketches and photos of the Alte Pinakothek in Döllgast's primer Häuser Zeichnen.

By 1946, around the time to which his sketch of the Alte Pinakothek later published in Häuser Zeichnen dates, the museum was quite literally a ruin. He watched its further demise first-hand:

"In front of our windows in Arcisstrasse, the mountain of rubble grew ever higher and the façade opposite us ever more naked. Thieves throw down Raffael and twenty-four others, and everything that sat atop sheet metal at the Pinakothek.... And so it continued until 1947-48." 4

Döllgast's first design for the building's reconstruction also dates to $1946 .{ }^{5}$ Reconstruction did not begin until $1952^{6}$ and Döllgast's work on the building continued until 1973. It was a fraught relationship, however, and his sense of embattlement resounds in the Journal Retour sketch.

\section{RECONSTRUCTION}

Leo von Klenze's Alte Pinakothek (1820-36) was part of the ambitious building agenda of King Ludwig I of Bavaria. The museum's deceptively simple rectangular plan spatialized a teleological reading of painting culminating in the School of Rubens. The main entrance was on its short side, facing east towards the old city center. The primary stair filled the southeast corner. Along the north side were rows of enfilade "cabinets" for smaller works. Important paintings were located in top-lit galleries at the building's center, and along the south-facing wall were no art works at all but instead, a loggia, decorated with frescos in the style of Raphael.

Döllgast immediately made several decisive changes to Klenze's architecture: he chose to relocate the entry and primary stair to the south wall, where the original service entrance had been; rather than restoring Klenze's hipped roofs, he chose to cover the building along its entire length with a single pitched roof; and to support that roof across the gap left in the south wall by a bomb, he installed steel columns 18.695 meters tall, positioned in the rhythm of Klenze's 
still-extant lonic columns. In the first phase of construction beginning in 1952, one flight of stairs was built and repairs to smaller gaps were made using bricks of the same format recovered from a ruined neighboring barracks. Apparently pleased at the end of this phase, Döllgast organized a public exhibition of photographs in the partially stabilized museum from September 9 - October 10, 1954.

Unfortunately, granting access to the architectural and political community became occasion for a vitriolic debate about Döllgast's approach. This was not simply a polemical struggle between historical re-creation and a freer interpretation of restoration. Rather, it was the provisional and mundane quality of what Döllgast had completed by 1954, particularly the construction details, that provoked such strong reaction. The new roof, for example, differed from Klenze's in both form and in the way it met the exterior walls. Rather than being concealed behind a stone parapet, the new roof eaves overhung the South façade and ended in a gutter feeding into exposed standard downspouts. This detail was, and is, more familiar on a simple house than a Neoclassical public building. The long, thin round steel columns supporting the roof were evocative of scaffolding or unfinished construction. Even the journalist Hans Eckstein, elsewhere a defender modernist public building including the beleagured Hans Schwippert's Bundestag, ${ }^{7}$ took offense. He wrote,

"Certainly had the question only been that of how the Pinakothek's ruins could again be made usable as a gallery at the smallest possible expense, then Döllgast's achievement would have to meet with unlimited admiration. But the goal would have to have been... somewhat higher, namely the resurrection of one of the most magnificent monuments of Munich Classicism....not the reconstruction of its naked, raw form." ${ }^{8}$

Döllgast's architectural language should have come as no surprise even to his critics. His prior projects in Munich were
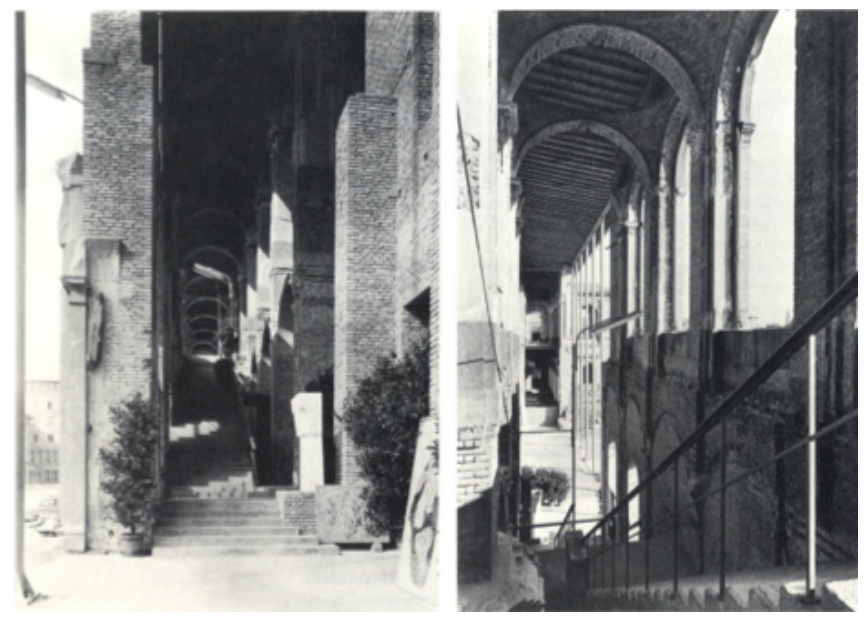

Figure 5: Images of the newly stabilized Pinakothek with Döllgast's provisional entrance, 1954. all very much in the public eye, among them the renovations of St. Bonifaz completed in 1950 and the Südfriedhof Cemetery, a project contemporaneous with the first phase of the Alte Pinakothek. In both, the damaged brick walls had been repaired in salvaged brick and left largely unplastered. Simple, openwork timber roof structures covered the church and the area along the cemetery wall.

The kinship between the church, the cemetery and the museum extends beyond the exposed timber roof structure and salvaged bricks. Döllgast's metalwork details share a common language across these projects. He preferred to use flat sections, as thin as possible in profile. The minimal fillet in which handrails or balusters end, underlines the effect of attenuation; there is an unmistakable affinity with the slightly overdrawn, arched ends Döllgast used in his lettering. Despite similarities to Biedermeier or Jugendstil, however, these mannerisms never locate themselves definitively within a nameable style.

The metal fountain at the Südfriedhof exemplifies his design sensibility at that time. Located near a heavily buttressed wall, the low, flat basin is surrounded by a deep rim and fed by two water pipes no more than an inch or so in diameter. The pipes emerge matter-of-factly from the ground, are held against the wall by a simple rosette and then bend 90 degrees to reach the basin, offset from the wall by a few feet. Additional flat section metal supports, bolted to the middle of the fountain's surround, stabilize the pipes, which bend again in exactly the same arc they define against the wall. The spouts are formed by trimming this arc at less than its full right angle leaving a fillet like that of Döllgast's handrail details. The support structures, bent in an isosceles triangle, recall the form of saw horses. Both quotidian and mannerist in form, the fountain reads equally as absolutely functional - after all, it is nothing more than plumbing lines and saw-horse-like supports - and as artfully attenuated.

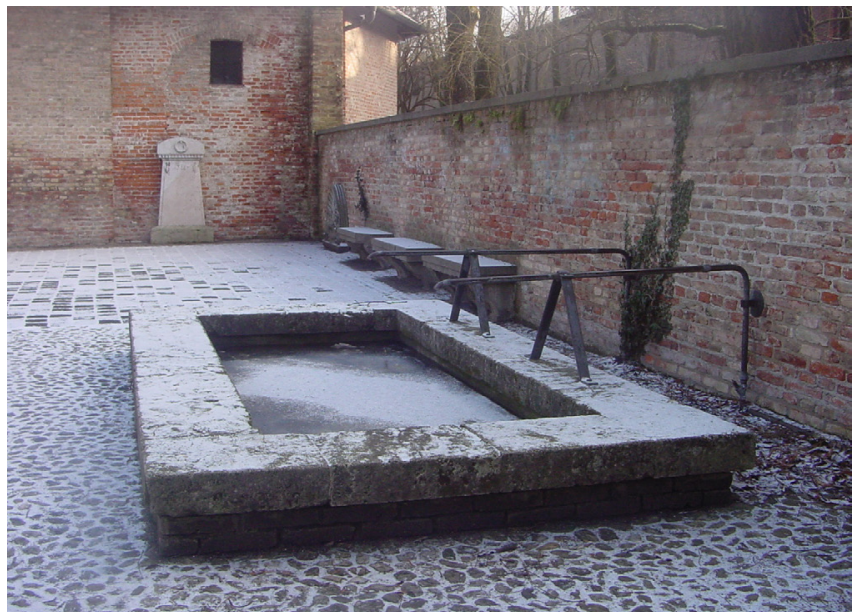

Figure 6: Fountain at the Südfriedhof. Photo by author. 
The Alte Pinakothek in 1954 was likewise no more a "reconstruction of its naked, raw form" than the fountain was an unmodulated answer to a functional demand. Döllgast's eye for the everyday and for the minimum flourish balanced an authorial hand against the staging of architectural histories large and small. The Alte Pinakothek functions iconographically, through the double spolia of the damaged original structure, as a representative of a moment in which Munich strove for political and cultural greatness, and the salvaged bricks used for repair, as symbolic of penance for the war. But it also operates with other histories and values: Döllgast's detailing also references anonymous, traditionally crafted artifacts of everyday life, juxtaposed to a controlled, individualistic artistic expression. The closely observed everyday as referent locates his architecture outside the discourses of "modern or unmodern."

\section{RECEPTION}

Despite the decades-long battle around its renovation, the Alte Pinakothek garnered little attention in the architectural press on its completion in 1957. It was not until the mid1970s, a period of historicizing debates in architecture and of German reconsideration of accounts of the war, that the building gained prominence.

The emergent tendency to celebrate Döllgast as a master of historically-sensitive Modern architecture is captured in a 1974 obituary. The author, Paulhans Peters, wrote,

"...he was truly one of the first creative preservationists that we had in Germany after the war. Today, most people have forgotten that he belonged to the very few by virtue of whose efforts the Alte Pinakothek was not demolished and replaced by something 'contemporary.' With his suggestion, he showed how one could close up a hole torn open by bombs without replacing everything as if nothing had happened. His repair work strove to let the building's scars remain visible ....It is certain that in the future, Döllgast's modesty of built means and his reverence for history will again become qualities to strive for - namely when our ideology of perfectionism has run itself into the ground."

Peters' text introduces the major tropes of Döllgast's posthumous reception: creative preservationism, repair without "replacing everything as if nothing had happened", "reverence for history" and "modesty of built means."

New interest in the Alte Pinakothek began in earnest with the 1978 exhibition 'Neues Bauen in alter Umgebung' (New Building in an Old Context). The exhibition, in a church renovated by Döllgast, included an eclectic selection of architectural projects and quotations. The catalogue cover featured a Carlo Scarpa window. Christian Norberg-Schulz, proponent of a neo-phenomenological architectural history, contributed an essay. Texts from authors ranging from John

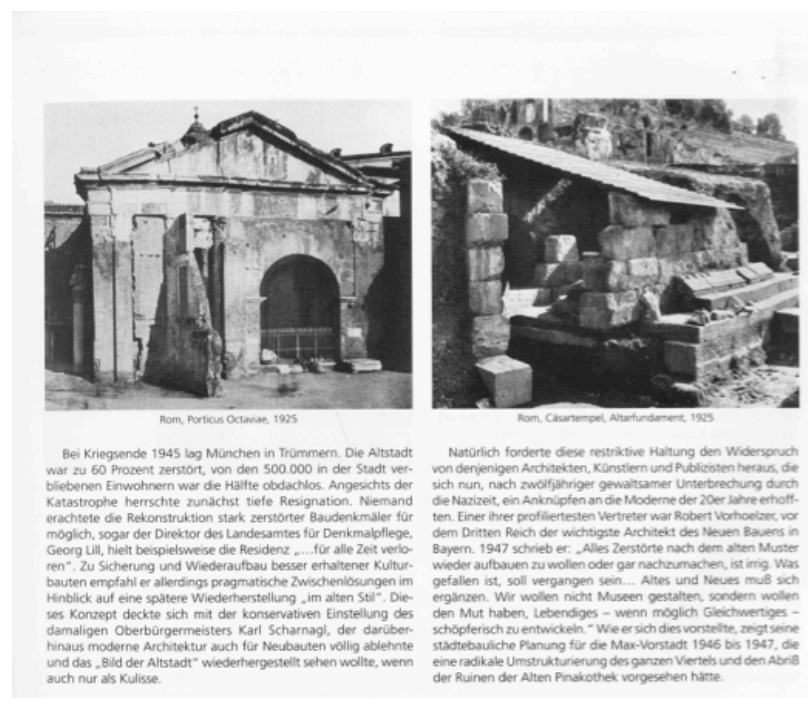

Figure 7: Images of archeological sites from the 1920s, in the 1998 monograph Von den Spuren (On Traces)

Ruskin to Adolf Loos to Theodor Adorno were cited. The Alte Pinakothek was praised for the "sparing use of very simple materials such as salvaged brick, steel pipe and concrete" to make "the renewed building a Gesamtkunstwerk, which permits recognition of its history."

The avalanche of interpretive research, articles and books on Döllgast since then has primarily followed this line, although there are several significant exceptions. Analogy to archeology, understood as the careful stewardship of ruins, is a recurrent theme. The 1998 monograph Von den Spuren: interpretierender Wiederaufbau im Werk von Hans Döllgast ('From the Traces: Reconstruction in the Work of Hans Döllgast') went so far as to include illustrations of roughly contemporaneous archeological sites as a source for Döllgast's buildings "which told their own history." 10 In these cases, Döllgast's posthumous reception takes literally his caricature of the Alte Pinakothek, sheltered beneath a protective umbrella.

\section{A MASON WHO HAS LEARNED LATIN?}

But there is reason to be suspicious of this interpretation. Döllgast's Häuser Zeichnen avers the simple trade plied by the sketcher of houses on the first page, with a sketch by "little three year old Hanna Blümel" of her town. But on the next page, Döllgast tips his hand. He writes:

"What does one draw? Jacob Burckhardt's answer to Alliot, his friend, was always: Situations .... One draws: something like a bridge at a highway, part of a city model, a garden shed, the fireplace, the vespa, the hansome cab, the donkey cart simply everything that has a more than trivial form." ${ }^{11}$

Burckhardt as cited here does not appear in his usual guise, the major figure in 19th century Renaissance art history, teacher of Heinrich Wöfflin and proponent of "art history without names." Instead, Döllgast quotes a letter - intimate, 
un-rhetorical speculation on the act of drawing. In his choice of quotation, Döllgast has indicated his own erudition, implying his thorough knowledge of Burckhardt, and his own affiliation with an "art history without names." Clearly, Döllgast is as interested in discerning the "important and typical" not only in architecture but in everyday life, in "everything that has a more than trivial form." The drawings on the same page of Goethe's garden house and Mozart's home reinforce the same idea: even high culture resides in everyday surroundings.

\section{RIEGL}

It is safe to assume that Döllgast, who spent his formative years as a young architect under Peter Behrens in Berlin and Vienna 1923-7, was familiar with the ideas of Alois Riegl. Döllgast's time in Vienna coincides with two annotated posthumous re-publications of Riegl's most significant books, Die spätrömische Kunstindustrie, first published in 1901 and reissued in 1927; and his study Der moderne Denkmalkultus: Sein Wesen und seine Entstehung ('The Modern Cult of Memorials: Its Essence and Genesis'), first commissioned in 1903 and reprinted in Riegl's Gesammelte Aufsätze of 1928. Döllgast would certainly have encountered Riegl's writings through his circle of colleagues: Behren's reliance upon Riegl's propositions is well documented. Because of Döllgast's adamantly anti-intellectual stance as constructed and reinforced in his own publications, and because little attention was given to auditing his book collection, however, there is no irrefutable evidence that Döllgast read Riegl's texts.

I would nonetheless like to highlight two aspects of Riegl's text on monuments in the context of re-reading the Alte Pinakothek. The first is the conviction that history is more than a series of events to be commemorated in the "intentional" monument. The other is that every monument, intentional or not, represents an overlay of values projected onto it by its producers and equally, by its different audiences over time.

Riegl argued that in addition to artifacts intended to recall a person or event of importance, any artifact could come to be considered a monument once sufficient time had passed between its production and the moment when it came to be seen as witness to part of a larger history - a monument produced unintentionally, and instead, granted that status through reception. In the unintentional monument, history is understood as Kulturgeschichte (cultural history).

Since the passage of time is inherent to the definition of monument as a trigger to memory, Riegl inferred, then the physical marks of time's passage, progressive ruination, are also an intrinsic value of the monument, what he called age value. In addition to age value, he argued, a monument represents an overlay of widely ranging and sometimes conflicting values. The scope of these values, and the way they

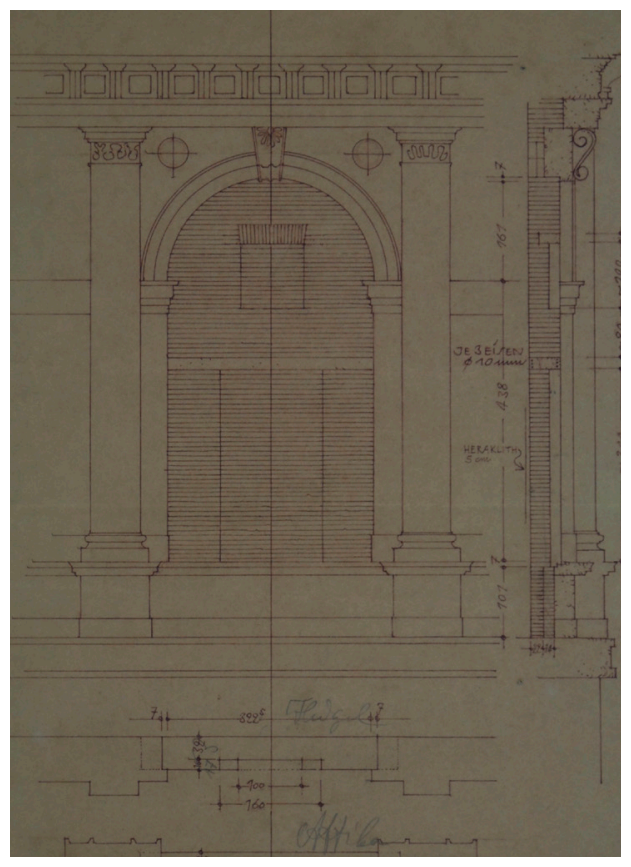

Figure 8: Sections through an infilled niche and exterior facade, Alte Pinakothek. TU Munich Architecture Museum

contribute meaning to the monument are relevant in discussing much more comprehensively Döllgast's treatment of the Alte Pinakothek.

\section{TECHNICS AND CULTURE}

Thanks to the stewardship of the Technical University of Munich Architecture Museum, Döllgast's building has received deserved attention and his drawings for the decadeslong project are largely catalogued. ${ }^{16}$ The only uncatalogued drawings are technical drawings; significantly, the building's technical aspects have never been heralded, as if admitting the renovation's technical scope might somehow undermine the building's more celebrated qualities. These drawings, ranging from structural calculations and shop drawings from the concrete manufacturer to interior casework details to the heating and ventilation diagrams, reveal that the building was not merely lightly-touched. In actuality, Döllgast constructed an entirely new museum within the ruins of the old.

Döllgast often rendered his post-war reconstructions using expressive pencil lines to denote the brickwork: the exposed courses demarcate repaired areas. In the story of the Pinakothek, the salvaged bricks have assumed mythic status: because the salvage bricks matched the format of the Alte Pinakothek's masonry, craftsmanship alone has received credit for the seamless results. But craft alone cannot explain the architectural orchestration of the concrete reinforcing inserted into the brick walls.

Like bearing structural requirements, climatization appropriate to a 20th century museum also had to be accommodated in the shell of Klenze's building. A basement plan shows the routing of all conduit needed for a hot water/steam hybrid heating system: hot water and return pipes; steam pipes; and 


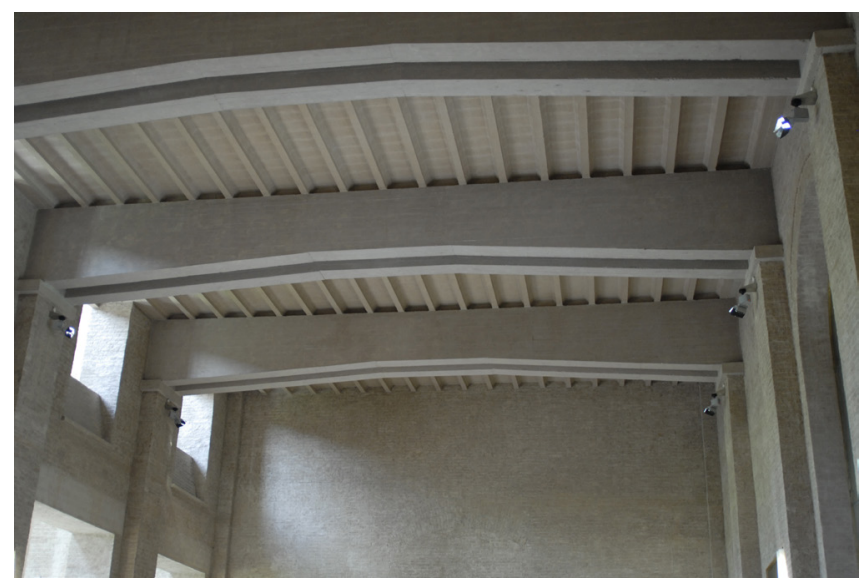

Figure 9: Entry vestibule, Alte Pinakothek. Katzenbach concrete beams in the vestibule ceiling. Photo by author

pipes for condensate return. A section drawing depicts the location of a new concrete beam just below a Klenzian cornice line, and various apertures for air registers. The interior wall is revealed to be a concrete frame within a brick veneer shell: the apparently solid walls had been rebuilt as hollow and the basement threaded with trenches and gaps to allow conditioned air to circulate through the building.

The ground floor is heated by a hot-water radiant system, located in a plenum below the limestone pavers. Döllgast's detail is unusual, showing the heating pipes affixed to a cement board within the plenum rather than cast into the concrete subfloor. The technique resembles Roman hypocaustic heating more than typical radiant systems. His invention within technical detail again speaks to the architect's more than modest ambitions. A drawing from Döllgast'soffice for the configuration of new foundations and building systems trenches in the basement proves that the architect left nothing to chance.

There are, of course, also drawings of details one would expect a careful architect to consider: doors, casework and metal work finishes. These drawings reveal the precision with which the simple "detail-less" finishes had to be planned. The door to the public restrooms beneath the main stair is rabetted to be almost flush to built-in metal doorframe. The doubleheight pivot hinge doors throughout the galleries were studied as variations on traditional board-and-batten doors. Custom bronze door handles and plates, made to match the recessed bronze doorframes, recall the Südfriedhof fountain: simple except for a slight fillet. In all the interior finishes, a kinship with vernacular building is pronounced. Technology is embedded in the building's structure and threaded through its cavities, while the architectural expression references the timeless everyday. In this sense, the museum could be seen as the bearer of all Riegl's categories: newness value, use value, historical value, age value and art value at once, far more
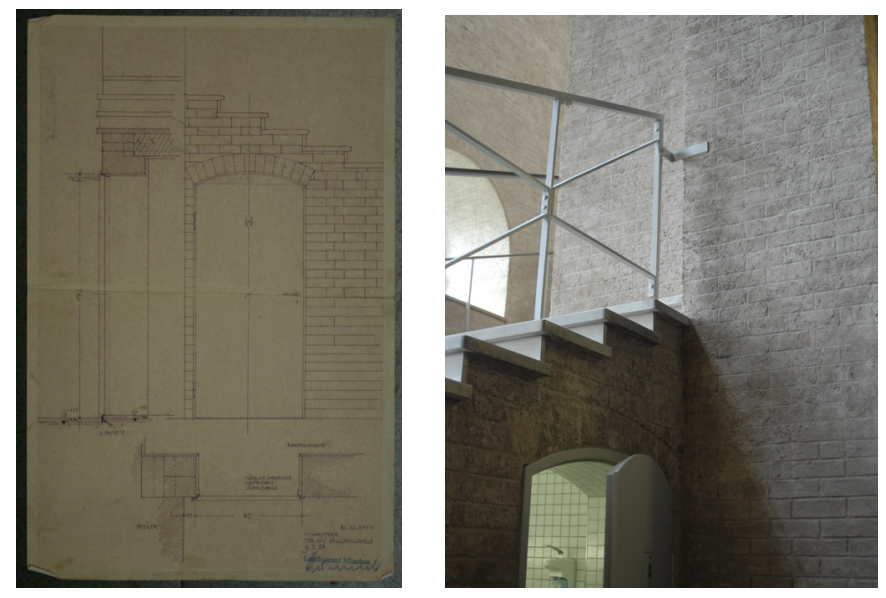

Figure 10: Detail drawing and photograph of restroom door beneath the salvaged brick stair. TU Munich Architecture Museum. Photo by author.

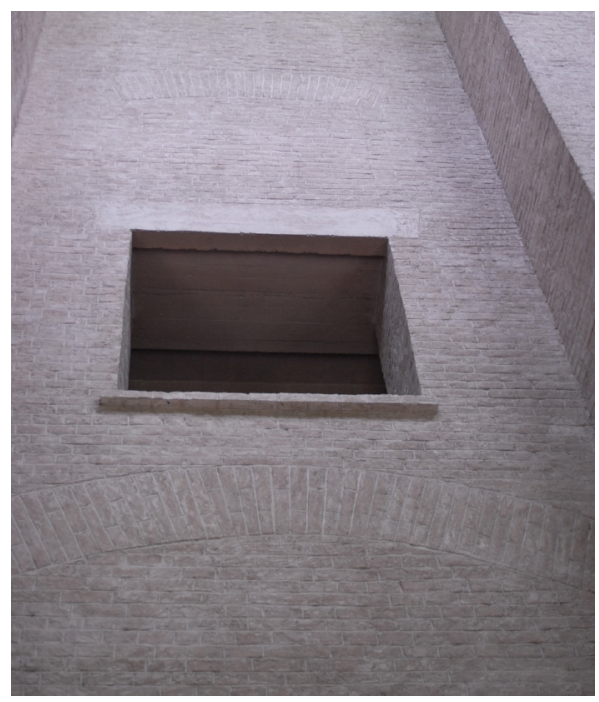

Figure 11: Entry vestibule. Alte Pinakothek, demonstrating the integration of concrete bearing structure, visible in the opening and at the lintel, with salvaged brickwork. Photo by author

than an exclusively iconographic interpretation of the façade can encompass.

It would be wrong, too, to overlook the fine line that Döllgast walked between the vernacular and the folkloric, or the repression of technology in the interest of image. Given his neo-vernacular architectural language and the invisibility of the supporting technology, it is difficult not to see Döllgast's interests relative to those of such architects as Paul Schmitthenner. In addition to certain similarities in appearance based on board and batten construction, Schmitthenner's enormous door for the Reichsbahn train depot, built as part of the symbolic building program during the Third Reich to represent a mythic Germanic architectural tradition, relied on high-precision technology in the form of specially engineered hinges and closures which made its appearance possible. The interdependence of technology and image remains unspoken in Schmitthenner's doors; the relationship between technology and image in Döllgast's case merits close attention. 


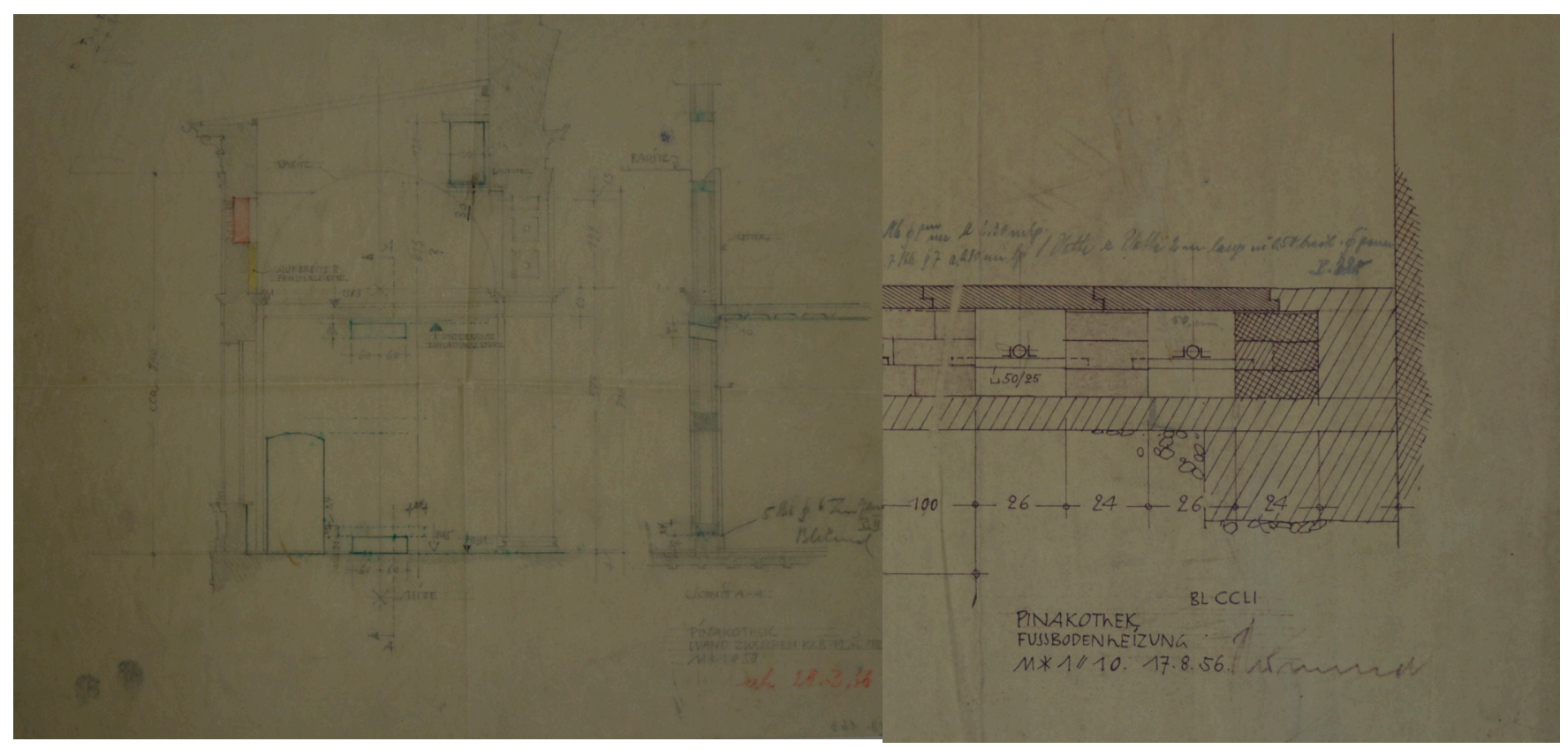

Figure 12: Section drawing showing HVAC installations. TU Munich Architecture Museum (left); Detail section of the lobby radiant heating system showing the built up concrete construction below the limestone floor pavers. TU Munich Architecture Museum.(right)

\section{CONCLUSION}

To belie the building's technical muscle and to accept that its grafted façades alone sufficiently explain its relation to history and memory ignores the overlay of characteristics, which give the Alte Pinakothek its capacity to represent as a monument - its multiple historical referents and intersections of historical value, age value, newness value, art value and even use value. The capacity - indeed the necessity - for a monument to support such complexity in its representation of history as dynamic and continuous is Riegl's argument; it enriches greatly the potential for receiving all of Döllgast's museum, not only its iconic facades. Döllgast understood how to play the physical remnants of history as great events, represented by Klenze's Classicism, against history as Kulturgeschichte, represented by his use of everyday building techniques and quasi-vernacular authorial flourishes. It is also these neo-vernacular referents, not attributable to a specific era or style, which lend Döllgast's building its celebrated capacity denote the passage of time as material, evoking history writ large and small

\section{ENDNOTES}

1 Hans Döllgast and Franz Kiessling, Journal retour, Faks.-Ausg. ed. (Salzburg ; München: Pustet, 2003). V. 2, 12.

2 See Eckstein, 'Ist das Bonner Bundeshaus zu schlecht gebaut?', in Die neue Zeitung 19.8.1950.

3 Döllgast et al., Op. Ci. See footnote 55 on p. 66. Erich Altenhöfer quotes Hans Eckstein's article in the Süddeutsche Zeitung v. 9/10.10.19547.

4 Peter Paulhans, "Zum Tod von Peter Celsing, Hans Döllgast und Louis Kahn," Der Baumeister 71(May, 1974). 489.

5 Franz Peter and Franz Wimmer, Von den Spuren: Interpretierender Wiederaufbau im Werk von Hans Döllgast (Salzburg: Anton Pustet, 1998). Preface.
6 Ibid. 4/5

7 Riegl died in 1905.

8 The 1927 edition was edited by Otto Pächt, web, March 28, 2012 http:// www.dictionaryofarthistorians.org/pachto.htm and was published by the Österreichisches Archälogisches Institut.

9 Stanford Anderson, Peter Behrens and a New Architecture for the Twentieth Century (Cambridge, Mass.: MIT Press, 2000).

10 The same holds true, for example, of Hans Schwippert, whose references to Kunstwollen in his term Wohnwollen during the Darmstadt Gespräche of 1951, although redolent of Riegl's ideas, cannot yet be definitively attributed to firsthand knowledge of Riegl.

11 http://www.architekturmuseum.de/sammlung/index.php

12 Riegl died in 1905.

13 The 1927 edition was edited by Otto Pächt, web, March 28, 2012 http:// www.dictionaryofarthistorians.org/pachto.htm and was published by the Österreichisches Archälogisches Institut.

14 Stanford Anderson, Peter Behrens and a New Architecture for the Twentieth Century (Cambridge, Mass.: MIT Press, 2000).

15 The same holds true, for example, of Hans Schwippert, whose references to Kunstwollen in his term Wohnwollen during the Darmstadt Gespräche of 1951, although redolent of Riegl's ideas, cannot yet be definitively attributed to firsthand knowledge of Riegl.

16 http://www.architekturmuseum.de/sammlung/index.php 